\title{
Multiple metabolic abnormalities in normal glucose tolerant relatives of NIDDM families
}

\author{
D.B. H umphriss ${ }^{1}$, M.W. Stewart ${ }^{1}$, T. S. B errish ${ }^{1}$, L .A . B arriocanal ${ }^{1}$, L. R . Trajano ${ }^{1}$, L . A . A shworth ${ }^{1}$, M . D . B rown ${ }^{1}$, \\ M. M iller ${ }^{1}$, P.J . A very ${ }^{2}$, K . G . M . M . A Iberti ${ }^{1}$, M . Walker ${ }^{1}$
}

${ }^{1}$ Human Diabetes and Metabolism Research Centre and Department of Medicine, University of Newcastle upon Tyne, UK

${ }^{2}$ Department of Statistics, University of Newcastle upon Tyne, UK

Summary Non-diabetic first degree relatives of noninsulin-dependent diabetic (NIDDM) families are at increased risk of developing diabetes mellitus, and have been studied to identify early metabolic abnormalities. Hormone concentrations measured by specific enzyme immunoassays were assessed in non-diabetic relatives of North European extraction, and control subjects with no family history of diabetes were matched for age, sex and ethnicity. A 75-g oral glucose tolerance test was conducted and those with newly diagnosed NIDDM were excluded. Basal insulin resistance was determined by homeostasis model assessment (HOMA), and hepatic insulin clearance by C-peptide:insulin molar ratio. Relatives $(n=150)$ were heavier (BMI: $p<0.0001)$ than the control subjects $(n=152)$, and had an increased prevalence of impaired glucose tolerance $(15$ vs $3 \%, p<0.01)$. The relatives had increased fasting proinsulin levels and decreased C-peptide levels following the glucose load, while insulin levels were increased at all time points. To examine whether the differences in hormone levels were secondary to the differences in glucose tolerance and adiposity, we studied 100 normal glucose tolerant relatives and control subjects pairmatched for age, sex, waist-hip ratio and BMI. The differences in proinsulin levels were no longer apparent. However, the relatives remained more insulin resistant, and had decreased C-peptide levels and Cpeptide:insulin ratios at all time points. In conclusion, we have identified several metabolic abnormalities in the normal glucose tolerant relatives, and propose that the decreased hepatic insulin clearance helps to maintain normoglycaemia in the face of combined insulin resistance and decreased insulin secretion. [Diabetologie (1997) 40: 1185-1190]

Keywords C-peptide, proinsulin, insulin, insulin secretion, insulin resistance, insulin clearance, families, adiposity, glucose intolerance.
Non-insulin-dependent diabetes mellitus (NIDDM) is a complex metabolic condition characterised by both impaired insulin secretion and insulin resistance [1]. It is also recognised that elevated circulating

Received: 11 February 1997 and in revised form: 29 April 1997

Corresponding author: Dr. M. Walker, Department of Medicine, The Medical School, Framlington Place, Newcastle upon Tyne, NE2 4HH, UK

A bbreviations: NIDDM, Non-insulin-dependent diabetes mellitus; IGT, impaired glucose tolerance; WHR, waist:hip ratio; CV, coefficient of variation; NEFA, non-esterified fatty acid; HOMA, homeostasis model assessment; IVGTT, intravenous glucose tolerance test. proinsulin levels are an important and consistent feature of NIDDM [2-5], and may represent a specific defect of pancreatic beta-cell function. There is continuing debate as to whether insulin deficiency or insulin resistance represents the primary abnormality which predisposes to the development of NIDDM [6], although it is clear that comparative insulin deficiency is a sine qua non for NIDDM to develop [7].

In an attempt to identify the early fundamental abnormalities, non-diabetic first degree relatives of NIDDM patients have been studied, as they have a $40 \%$ lifetime risk of progressing to diabetes [8]. However, such an approach has so far failed to clarify matters, as some studies have found a principal defect of insulin secretion [9-13], several have suggested that 
insulin resistance is the primary abnormality [14-19], while three studies have reported evidence for both impaired insulin secretion and action in normal glucose tolerant relatives [20-22]. A number of factors might account for these divergent observations, and include differences in study populations, for example in ethnicity, and methodological differences. Certainly, insulin resistance appears to be of fundamental importance in the Mexican-American [18] and Pima Indian populations [23], while evidence of decreased insulin secretion has tended to come from studies of Caucasians [9-13, 20-22].

It is now well recognised that proinsulin-like molecules can cross-react in conventional insulin radioimmunoasays [24], and this could have been important in earlier studies $[14-17,20]$ in which "hyperinsulinaemia" was detected in non-diabetic relatives and presumed to represent insulin resistance. This has been explored further with the advent of specific hormone assays. Proinsulin levels have been reported to be normal [5,25] and slightly increased [26] in normal glucose tolerant relatives of North European extraction, and increased in non-diabetic Mexican Americans with a parental history of diabetes [18].

The aim of the present study, therefore, was to explore changes in beta-cell function, insulin metabolism and insulin action using specific hormone assays in non-diabetic relatives of NIDDM families of North European extraction and control subjects with no family history of diabetes.

\section{Subjects and methods}

Subjects. We recruited 154 non-diabetic first degree relatives (age 20-65 years) of NIDDM patients from 62 families of North European extraction with two or more living NIDDM patients. The relatives were related to the NIDDM family members in the following ways; 108 were offspring, 2 were siblings, and 44 were both offspring and siblings. For comparison, 154 non-diabetic control subjects with no family history of diabetes and matched for age, sex and ethnic background were recruited from a randomly selected subgroup of the local background population. This subgroup comprised over 1000 residents of the Newcastle and North Tyneside District that had been selected from the Family Health Services Authority Register for a health survey conducted by the Department of Epidemiology, University of Newcastle upon Tyne. Ethnicity was based upon both parents being of North European origin. None of the subjects was taking agents known to influence lipid or glucose metabolism. Informed written consent was obtained from all subjects and the study was approved by the Newcastle and North Tyneside District Ethics Committee.

P rotocol. Subjects were studied following an overnight fast and a 24-h period of abstinence from alcohol and vigorous exercise. An indwelling cannula was placed in an antecubital vein for blood sampling. At $0 \mathrm{~min}, 75 \mathrm{~g}$ of glucose $(388 \mathrm{ml}$ degassed Lucozade, Smithkline Beecham, Brentford, UK) was given orally; blood was sampled fasting ( $0 \mathrm{~min})$, and 30 and $120 \mathrm{~min}$ following the glucose load. Glucose tolerance was classified according to 1985 World Health Organization criteria [27], and those subjects classified as having impaired glucose tolerance (IGT) had a repeat oral glucose tolerance test within 2 months to identify subjects with persistent IGT. Waist: hip ratio (WHR) was assessed by standard methods [28], and blood pressure was measured after 10 min resting supine.

$\mathrm{L}$ aboratory methods. Blood glucose was measured by the glucose oxidase method using a Yellow Springs glucose analyser (inter-assay coefficient of variation [CV] 3.5\%: Yellow Springs Instrument Company, Yellow Springs, Ohio, USA). Serum creatinine (Boehringer Mannheim, Lewes, UK) and serum triglyceride (Roche, Welwyn Garden City, UK) concentrations were measured using commercial kits. Plasma non-esterified fatty acid (NEFA) levels were measured by centrifugal enzymatic analysis (inter-assay CV 3.0\%, Wako, Neuss, Germany). Serum for hormone determinations was separated at $4{ }^{\circ} \mathrm{C}$ and stored at $-40^{\circ} \mathrm{C}$, and relative and control subject samples were subsequently analysed together in batches. Total proinsulin, intact proinsulin, insulin and C-peptide concentrations were all measured by specific enzyme immunoassays (DAKO Diagnostics Ltd, Ely, UK). For the insulin assay (inter-assay CV $4.8 \%$ at $34 \mathrm{pmol} / 1)$, the detection limit was $6 \mathrm{pmol} / 1$ with $0.3 \%$ cross-reactivity with both intact and 32-33 split proinsulin, and $0 \%$ cross-reactivity with C-peptide. For the C-peptide assay (inter-assay CV $3.5 \%$ at $160 \mathrm{pmol} / \mathrm{l}$ ), the detection limit was $50 \mathrm{pmol} / 1$ with $63 \%$ and $73 \%$ cross reactivities with intact and 32-33 split proinsulins, respectively, and $0 \%$ cross reactivity with insulin. Both total (inter-assay CV $4.7 \%$ at $16 \mathrm{pmol} / \mathrm{l}$ ) and intact (inter-assay CV $6.6 \%$ at $10 \mathrm{pmol} / 1$ ) proinsulin assays had detection limits of $0.15 \mathrm{pmol} / 1$, and $0 \%$ cross-reactivity with insulin and C-peptide.

Statistical analysis. Basal insulin resistance was determined using the homeostasis model assessment (HOMA) modified from Matthews et al. [29]. Proinsulin:insulin and proinsulin:Cpeptide molar ratios are presented as percentages, and C-peptide:insulin molar ratios are shown as absolute values. Initial comparison of the two subject groups was by unpaired t-test. HOMA values and hormone concentrations and ratios were all $\log _{10}$ transformed to normalise distributions, and these data are presented as the geometric mean [range]. For the second analysis of normal glucose tolerant subjects, relatives and control subjects were individually pair-matched and analysed by paired t-test. For every variable, the differences were approximately normally distributed and so the data are presented as means for relatives and control subjects, and the SD of the differences. All analyses were conducted using the Minitab Statistical Package.

\section{Results}

Four relatives and two control subjects were diagnosed as having diabetes on oral glucose tolerance test and were excluded from further study. The remaining 150 relatives and 152 control subjects were matched for age and sex (Table 1) and all subjects had serum creatinine concentrations within the normal population range. BMI was significantly increased in the relatives, while WHR showed a similar trend $(p=0.07)$. The relatives also had increased basal insulin resistance $(p<0.0001)$ and a higher prevalence of IGT $(p<0.01)$. Blood glucose and serum 
Table 1. Anthropometric and metabolic characteristics of the non-diabetic relatives and control subjects

\begin{tabular}{|c|c|c|c|c|}
\hline & & $\begin{array}{l}\text { Relatives } \\
(n=150)\end{array}$ & $\begin{array}{l}\text { Control subjects } \\
(n=152)\end{array}$ & $p$ value \\
\hline \multicolumn{2}{|l|}{ Age (years) } & $39 \pm 10$ & $41 \pm 12$ & NS \\
\hline Sex (male, & & $66: 84$ & $72: 80$ & - \\
\hline \multicolumn{2}{|c|}{ BMI $\left(\mathrm{kg} / \mathrm{m}^{2}\right)$} & $27.4 \pm 5.1$ & $25.3 \pm 4.1$ & 0.0001 \\
\hline \multicolumn{2}{|l|}{ WHR } & $0.84 \pm 0.09$ & $0.82 \pm 0.11$ & NS \\
\hline \multicolumn{2}{|c|}{$\mathrm{HOMA}\left(\mathrm{mmol} \cdot \mathrm{mU}^{-1} \cdot \mathrm{l}^{-2}\right)$} & $2.3[0.5,10.9]$ & $1.6[0.2,8.3]$ & 0.0001 \\
\hline $\begin{array}{l}\text { Blood } \\
\text { glucose } \\
(\mathrm{mmol} / \mathrm{l})\end{array}$ & $\begin{array}{l}\text { Fasting } \\
30 \\
120\end{array}$ & $\begin{array}{l}4.8 \pm 0.9 \\
7.9 \pm 1.5 \\
5.6 \pm 2.3\end{array}$ & $\begin{array}{l}4.6 \pm 0.6 \\
7.6 \pm 1.4 \\
5.1 \pm 1.5\end{array}$ & $\begin{array}{l}0.01 \\
0.05 \\
0.01\end{array}$ \\
\hline $\begin{array}{l}\text { C-peptide } \\
(\mathrm{pmol} / \mathrm{l})\end{array}$ & $\begin{array}{l}\text { Fasting } \\
30 \\
120^{\prime}\end{array}$ & $\begin{array}{c}465[70,1970] \\
1588[480,4480] \\
1524[90,4660]\end{array}$ & $\begin{array}{r}486[130,1520] \\
1790[420,5100] \\
1918[600,5280]\end{array}$ & $\begin{array}{l}\text { NS } \\
0.04 \\
0.0014\end{array}$ \\
\hline $\begin{array}{l}\text { Intact } \\
\text { proinsulin } \\
(\text { pmol/l) }\end{array}$ & $\begin{array}{l}\text { Fasting } \\
30^{\prime} \\
120^{\prime}\end{array}$ & $\begin{array}{r}4[1,41] \\
9[3,49] \\
18[5,94]\end{array}$ & $\begin{array}{c}3[1,34] \\
9[1,44] \\
18[5,112]\end{array}$ & $\begin{array}{l}0.05 \\
\text { NS } \\
\text { NS }\end{array}$ \\
\hline
\end{tabular}

Data presented as mean \pm SD or geometric mean [range]

insulin concentrations were significantly raised in the relatives at all time points (Table 1). Fasting total and intact proinsulin levels were also increased in the relatives, but not after the glucose load. Conversely, Cpeptide levels were significantly lower in the relatives following the glucose load.

To investigate whether the differences in the hormone levels between relatives and control subjects were secondary to the differences in glucose tolerance and adiposity, normal glucose tolerant (120 min glucose less than $6.7 \mathrm{mmol} / \mathrm{l})$ relatives and control subjects were pair-matched for age, sex, WHR and BMI. This gave 45 male pairs matched for age (means for relatives, control subjects [SD of differences]; 37, 38 [4] years), BMI (26.3, 26.0 [1.5] $\left.\mathrm{kg} / \mathrm{m}^{2}\right)$, and WHR $(0.89,0.89$ [0.06]), and 55 female pairs similarly matched for age $(39,39$ [5] years), BMI $\left(25.7,25.6\right.$ [1.7] $\left.\mathrm{kg} / \mathrm{m}^{2}\right)$, and WHR (0.77, 0.76 [0.05]). As differences between the relatives and control subjects for all variables were comparable in both sexes (i.e. no gender effect), the data for the male and female pairs are presented together. The prevalence of hypertension (blood pressure $\geq 160 / 95 \mathrm{mmHg}$ ) was comparable in the relatives $(1 \%)$ and control subjects $(3 \%)$ with one subject from each group using an antihypertensive agent (both amlodopine). The prevalence of hypertriglyceridaemia (fasting level $>2.5 \mathrm{mmol} / \mathrm{l}$ ) was also comparable in the relatives $(4 \%)$ and control subjects $(5 \%)$, and no subject had a value greater than $3.7 \mathrm{mmol} / \mathrm{l}$.
Table 2 summarises the metabolic data for the paired analyses. Basal insulin resistance remained significantly increased in the relatives. Fasting plasma non-esterified fatty acid (NEFA) levels were marginally lower in the relatives, although there were no differences between the groups following the glucose load. Total and intact proinsulin, and insulin concentrations were comparable between the two subject groups, while the C-peptide levels remained significantly decreased in the fasting and glucose-stimulated states. The C-peptide:insulin molar ratios were markedly decreased and the total proinsulin:C-peptide $(\%)$ ratios were increased in the relatives at all time points. Conversely, the total proinsulin:insulin (\%) ratios were similar in the two groups.

\section{Discussion}

Proinsulin, insulin and C-peptide levels were measured by specific immunoassays in non-diabetic relatives of NIDDM families and control subjects with no family history of diabetes. Considering all of the non-diabetic relatives $(n=150)$ and control subjects $(n=152)$, the key findings were that the relatives were more insulin resistant, and had increased insulin and decreased C-peptide concentrations. Total and intact proinsulin levels were also higher in the relatives in the fasting state. However, the relatives also had a higher prevalence of persistent IGT, and were also significantly heavier and tended to have a higher 
Table 2. Metabolic measurements for the 100 pair-matched normal glucose tolerant relatives and control subjects

\begin{tabular}{|c|c|c|c|c|c|}
\hline & & Relatives & Control subjects & SD of differences & $\mathrm{p}$ value \\
\hline$\overline{\operatorname{HOMA}\left(\mathrm{mmol} \cdot \mathrm{mU}^{-1} \cdot \mathrm{l}^{-2}\right)}$ & & 2.1 & 1.8 & 1.3 & 0.02 \\
\hline Blood glucose $(\mathrm{mmol} / \mathrm{l})$ & $\begin{array}{l}\text { Fasting } \\
30 \\
120\end{array}$ & $\begin{array}{l}4.5 \\
7.6 \\
4.7\end{array}$ & $\begin{array}{l}4.6 \\
7.4 \\
4.6\end{array}$ & $\begin{array}{l}0.8 \\
1.8 \\
1.4\end{array}$ & $\begin{array}{l}\text { NS } \\
\text { NS } \\
\text { NS }\end{array}$ \\
\hline NEFA (mmol/l) & $\begin{array}{c}\text { Fasting } \\
30 \\
120\end{array}$ & $\begin{array}{l}0.51 \\
0.31 \\
0.07\end{array}$ & $\begin{array}{l}0.58 \\
0.33 \\
0.08\end{array}$ & $\begin{array}{l}0.30 \\
0.24 \\
0.05\end{array}$ & $\begin{array}{l}0.03 \\
\text { NS } \\
\text { NS }\end{array}$ \\
\hline Insulin $(\mathrm{pmol} / \mathrm{l})$ & $\begin{array}{c}\text { Fasting } \\
30^{\prime} \\
120^{\prime}\end{array}$ & $\begin{array}{r}64 \\
529 \\
265\end{array}$ & $\begin{array}{r}56 \\
496 \\
246\end{array}$ & $\begin{array}{r}37 \\
387 \\
289\end{array}$ & $\begin{array}{l}\text { NS } \\
\text { NS } \\
\text { NS }\end{array}$ \\
\hline Total proinsulin (pmol/l) & $\begin{array}{l}\text { Fasting } \\
30^{\prime} \\
120^{\prime}\end{array}$ & $\begin{array}{l}11 \\
48 \\
67\end{array}$ & $\begin{array}{l}11 \\
48 \\
69\end{array}$ & $\begin{array}{r}9 \\
43 \\
71\end{array}$ & $\begin{array}{l}\text { NS } \\
\text { NS } \\
\text { NS }\end{array}$ \\
\hline C-peptide/insulin molar ratio & $\begin{array}{c}\text { Fasting } \\
30^{\prime} \\
120^{\prime}\end{array}$ & $\begin{array}{l}7.8 \\
3.5 \\
7.7\end{array}$ & $\begin{array}{r}11.0 \\
5.0 \\
10.8\end{array}$ & $\begin{array}{l}7.8 \\
2.1 \\
6.6\end{array}$ & $\begin{array}{l}0.0002 \\
0.0001 \\
0.0001\end{array}$ \\
\hline Total proinsulin/C-peptide ratio (\%) & $\begin{array}{l}\text { Fasting } \\
30^{\prime} \\
120^{\prime}\end{array}$ & $\begin{array}{l}2.8 \\
3.3 \\
5.4\end{array}$ & $\begin{array}{l}2.1 \\
2.3 \\
3.4\end{array}$ & $\begin{array}{l}1.9 \\
2.4 \\
8.3\end{array}$ & $\begin{array}{l}0.001 \\
0.0003 \\
0.01\end{array}$ \\
\hline Total proinsulin/Insulin ratio (\%) & $\begin{array}{c}\text { Fasting } \\
30 \\
120^{\prime}\end{array}$ & $\begin{array}{l}20 \\
10 \\
31\end{array}$ & $\begin{array}{l}22 \\
11 \\
33\end{array}$ & $\begin{array}{r}17 \\
6 \\
23\end{array}$ & $\begin{array}{l}\text { NS } \\
\text { NS } \\
\text { NS }\end{array}$ \\
\hline
\end{tabular}

All data are presented as the respective means and the SD of the differences

WHR. A key question, therefore, was whether the differences in hormone levels and insulin resistance between the two groups simply due to these differences in adiposity and glucose tolerance.

To address this issue, we pair-matched 100 normal glucose tolerant relatives and control subjects on the basis of age, sex, WHR and BMI. The striking observation was that important metabolic differences remained between the relatives and control subjects (Table 2). First, basal insulin resistance remained increased in the relatives. Although the HOMA index provides an indirect assessment of insulin sensitivity, it has been shown to be closely correlated $(r=0.88$, $p<0.0001$ ) with the index of insulin sensitivity ( $M$ value) derived from the hyperinsulinaemic euglycaemic clamp [29]. Other studies have reported insulin resistance in normal glucose tolerant relatives of NIDDM families [15-22], although the biochemical mechanisms remain to be fully defined. Decreased insulinstimulated glycogen deposition in skeletal muscle appears to be a key abnormality $[16,19]$, while physical fitness, an important determinant of insulin sensitivity in normal man [30], has recently been reported to be decreased in a comparable group of normal glucose tolerant relatives [22]. Second, C-peptide levels in the fasting and glucose stimulated states were decreased in the relatives indicating impaired insulin secretion. Thus, we have found evidence for both decreased insulin action and decreased insulin secretion in the normal glucose tolerant relatives that supports the observations of other recent studies [20-22].

This does, however, beg the question as to how the relatives maintain normoglycaemia in the presence of these two metabolic defects. One previously suggested mechanism involves a compensatory increase in glucose-mediated glucose disposal as determined using the frequent sampled intravenous glucose tolerance test (IVGTT) [21]. Our observations lead us to propose a second complimentary mechanism whereby peripheral insulin levels are maintained through a decrease in hepatic insulin clearance. The C-peptide:insulin ratio is an index of hepatic insulin clearance [31-33], and was found to be markedly decreased in the relatives (Table 2). Haffner and colleagues reported decreased hepatic insulin clearance in non-diabetic Mexican Americans when compared with non-Hispanic white control subjects [33], and proposed that it represented an adaptive response to maintain adequate circulating insulin levels in the presence of insulin resistance. An alternative explanation is that the decreased insulin clearance is simply secondary to some other metabolic abnormality in the relatives. Increased NEFA levels have been shown to decrease hepatic insulin clearance [34], and is thought 
to be the mechanism by which hyperinsulinaemia develops in subjects with abdominal obesity [35]. However, there was no evidence that this mechanism was important in the relatives in the present study. First, although visceral fat stores were not directly assessed, previous studies have reported a significant positive correlation between WHR and visceral fat stores as determined by computed tomography $[36,37]$. Importantly, WHR was one of the parameters used to pairmatch the normal glucose relatives and control subjects. Second, plasma NEFA levels were not increased in the relatives following the glucose load, and, indeed, were lower in the fasting state. Thus, the available evidence strongly suggests that the decreased hepatic insulin clearance in the relatives was not secondary to abdominal obesity, and this therefore provides support for an adaptive response the nature of which requires further investigation.

Hepatic insulin clearance is receptor-mediated and linked in part to intracellular insulin action [38]. Inhibition of rat hepatocyte insulin clearance and degradation has been shown to impair the action of insulin on amino acid but not glycogen metabolism [39]. The biological significance of decreased hepatic insulin clearance for hepatic metabolism in the normal glucose tolerant relatives requires further study, although it is interesting to note that hepatic glucose output was found to be normal in a group of comparable relatives of NIDDM families [16].

The elevated fasting total and intact proinsulin levels observed in the whole group of relatives (Table 1) were no longer apparent when the pair-matched normal glucose tolerant subjects were considered (Table 2). This suggests that the increased fasting proinsulin levels were secondary to the differences in glucose tolerance and adiposity, and is in keeping with other reports of normal proinsulin levels in normal glucose tolerant relatives [5, 25]. However, the reports that split proinsulin levels were increased during an IVGTT in comparable normal glucose tolerant relatives [26] and that total proinsulin levels were raised independently of metabolic factors in non-diabetic Mexican-Americans [18], suggests that subtle primary abnormalities of circulating proinsulin levels may be present in at-risk relatives under certain conditions.

As anticipated from the changes in the absolute hormone concentrations, the proinsulin:C-peptide ratio was increased in the normal glucose tolerant relatives, with no difference between the groups for the proinsulin:insulin ratios. This underlines the important point that the proinsulin:insulin ratio is not a reliable index of beta-cell function under conditions of altered hepatic insulin clearance, and under such circumstances, the proinsulin:C-peptide ratio should be used. Certainly a close and inverse relationship has been demonstrated between the proinsulin:C-peptide ratio and first phase insulin secretion as an index of beta-cell function [40].
In conclusion, we have identified multiple metabolic abnormalities in normal glucose tolerant relatives of NIDDM families. We propose that the potential impact of decreased insulin secretion and decreased insulin action to raise blood glucose levels is limited by compensatory mechanisms, one of which includes decreased hepatic insulin clearance that will increase peripheral insulin levels and help to maintain normoglycaemia. Longitudinal studies are clearly needed to delineate how these metabolic changes progress with time and contribute to the ultimate development of diabetes.

A cknowledgements. Thanks to Dr. C. Dark for technical support. The study was supported by the British Diabetic Association and Medical Research Council.

\section{References}

1. De Fronzo RA (1988) The triumvirate: $\beta$-cell, muscle, liver. A collusion responsible for NIDDM. Diabetes 37: 667-687

2. Temple RC, Carrington CA, Luzio CD et al. (1989) Insulin deficiency in non-insulin dependent diabetes. Lancet 1: 293-295

3. Ward WK, LaCava EC, Paquette TL, Beard JC, Wallum BJ, Porte D Jr (1987) Disproportionate elevation of immunoreactive proinsulin in type 2 (non-insulin-dependent) diabetes mellitus and in experimental insulin resistance. Diabetologia 30: 698-702

4. Davis SN, Piatti PM, Monti L et al. (1993) Proinsulin and insulin concentrations following intravenous glucose challenges in normal, obese and non-insulin-dependent diabetic subjects. Metabolism 42: 30-35

5. Birkeland KI, Torjesen PA, Eriksson J, Vaaler S, Groop L (1994) Hyperproinsulinaemia of Type II diabetes is not present before the development of hyperglycaemia. Diabetes Care 17: 1307-1310

6. Taylor SI, Accili D, Imai Y (1994) Insulin resistance or insulin deficiency. Which is the primary cause of NIDDM? Diabetes 43: 735-740

7. Alberti KGMM, Taylor R (1988) Aetiology of non-insulin dependent diabetes mellitus. In: Cameron D, Colagiuri S, Heding L, Kuhl C, Ma A, Mortimer R (eds) Non-insulindependent diabetes mellitus. Excerpta Medica Asia Ltd, Hong Kong, pp 35-42

8. Kobberling J, Tillil H (1982) Empirical risk figures for first degree relatives of non-insulin-dependent diabetics. In: Kobberling J, Tattersall R (eds) The genetics of diabetes mellitus. Academic Press, London, pp 201-209

9. Pimenta W, Korytkowski M, Mitrakou A et al. (1995) Pancreatic beta-cell dysfunction as the primary genetic lesion in NIDDM. JAMA 273: 1855-1861

10. O'Rahilly S, Turner RC, Matthews DR (1988) Impaired pulsatile secretion of insulin in relatives of patients with noninsulin-dependent diabetes. N Engl J Med 318: 12251230

11. Berntorp K, Lingarde F (1985) Impaired physical fitness and insulin secretion in normoglycaemic subjects with familial aggregation of type II diabetes. Diabetes Res 2: 151-156

12. Fernandez-Castaner M, Biarnes J, Camps I, Ripolles J, Gomez N, Soler J (1996) Beta-cell dysfunction in first degree relatives of patients with non-insulin dependent diabetes mellitus. Diabet Med 13: 953-959 
13. O'Rahilly SP, Nugent Z, Rudenski AS et al. (1986) Betacell dysfunction, rather than insulin insensitivity, is the primary defect in familial type 2 diabetes. Lancet 2: 360 363

14. Leslie RDG, Volkmann HP, Poncher M, Hanning I, Orskov H, Alberti KGMM (1986) Metabolic abnormalities in children of non-insulin-dependent diabetics. BMJ 293: 840-842

15. Warram JH, Martin BC, Krolewski AS, Soeldner JS, Kahn CR (1990) Slow glucose removal rate and hyperinsulinaemia precede the development of type II diabetes in the offspring of diabetic parents. Ann Intern Med 113: 909-915

16. Eriksson J, Franssila-Kallunki A, Ekstrand A et al. (1989) Early metabolic defects in persons at increased risk for non-insulin dependent diabetes mellitus. N Engl J Med 321: 337-343

17. Osei K, Cottrell DA, Orabella MM (1991) Insulin sensitivity, glucose effectiveness, and body fat distribution pattern in nondiabetic offspring of patients with NIDDM. Diabetes Care 14: 890-896

18. Haffner SM, Stern MP, Miettinen H, Gingerich R, Bowsher RR (1995) Higher proinsulin and specific insulin are both associated with a parental history of diabetes in non-diabetic Mexican-American subjects. Diabetes 44: 1156-1160

19. Vaag A, Henriksen JE, Beck-Nielsen H (1992) Decreased insulin activation of glycogen synthase in skeletal muscles of young nonobese Caucasian first-degree relatives of patients with non-insulin-dependent diabetes mellitus. J Clin Invest 89: 782-788

20. Elbein SC, Maxwell TM, Schumacher MC (1991) Insulin and glucose levels and prevalence of glucose intolerance in pedigrees with multiple diabetic siblings. Diabetes 40: 1024-1032

21. Henriksen JE, Alford F, Handberg A et al. (1994) Increased glucose effectiveness in normoglycaemic but insulin resistant relatives of patients with non-insulin dependent diabetes mellitus. J Clin Invest 94: 1196-1204

22. Nyholm B, Mengel A, Nielsen S et al. (1996) Insulin resistance in relatives of NIDDM patients: the role of physical fitness and muscle metabolism. Diabetologia 39: 813-822

23. Lillioja S, Nyomba BL, Saad MF et al. (1991) Exaggerated early insulin release and insulin resistance in a diabetesprone population: a metabolic comparison of Pima Indians and Caucasians. J Clin Endocrinol Metab 73: 866-876

24. Osei K (1990) Predicting type II diabetes in persons at risk. Ann Intern Med 113: 905-907

25. Beer SF, O'Rahilly S, Spivey RS, Hales CN, Turner RC (1990) Plasma proinsulin in first-degree relatives of type 2 diabetic patients. Diabetes Res 14: 51-54

26. Gelding SV, Andres C, Niththyananthan R, Gray IP, Mather H, Johnston DG (1995) Increased secretion of 32, 33 split proinsulin after intravenous glucose in glucose-tolerant first-degree relatives of patients with non-insulin dependent diabetes of European, but not Asian, origin. Clin Endocrinology 42: 255-264
27. World Health Organisation Expert Committee (1985) Second Report on Diabetes Mellitus. Technical Report, Series 727. World Health Organization, Geneva

28. Forbes GB (1990) The abdomen:hip ratio. Normative data and observations on selected patients. Int J Obesity 14: 149-157

29. Matthews DR, Hosker JP, Rudenski AS, Naylor BA, Treacher DF, Turner RC (1985) Homeostasis model assessment: insulin resistance and B-cell function from fasting plasma glucose and insulin concentrations in man. Diabetologia 28: 412-419

30. Berrish TS, Subhan FMM, Elliott C et al. (1996) Exercise capacity: an important determinant of insulin sensitivity in the insulin-stimulated state in normal man. Endocrinol Metab 3: 139-144

31. Savage PJ, Flock EV, Mako ME, Blix PM, Rubenstein AH, Bennett PH (1979) C-peptide and insulin secretion in Pima Indians and Caucasians: constant fractional hepatic extraction over a wide range of insulin concentrations and in obesity. J Clin Endocrinol Metab 48: 594-598

32. Buffington CK, Kitabchi AE (1994) Evidence for a defect in insulin metabolism in hyperandrogenic women with polycystic ovarian syndrome. Metabolism 43: 1367-1372

33. Haffner SM, Stern MP, Watanabe RM, Bergman RN (1992) Relationship of insulin clearance and secretion to insulin sensitivity in non-diabetic Mexican Americans. Eur J Clin Invest 22: 147-153

34. Svedberg J, Stromblad G, Wirth A, Smith U, Bjorntorp P (1991) Fatty acids in the portal vein of the rat regulate hepatic insulin clearance. J Clin Invest 88: 2054-2058

35. Sonnenberg GE, Hoffman RG, Mueller RA, Kissebah AH (1994) Splanchnic insulin dynamics and secretion pulsatilities in abdominal obesity. Diabetes 43: 468-477

36. Ashwell M, Cole TJ, Dixon AK (1985) Obesity: new insights into the anthropometric classification of fat distribution shown by computed tomography. BMJ 290: 1692-1694

37. Seidell JC, Oosterlee A, Deurenberg P, Hautvast JGAJ, Ruijs JHJ (1988) Abdominal fat depots measured with computed tomography: effects of degree of obesity, sex, and age. Eur J Clin Nutr 42: 805-815

38. Duckworth CD (1988) Insulin degradation: mechanisms, products, and significance. Endocr Rev 9: 319-345

39. Peavy DE, Edmondson JW, Duckworth WC (1984) Selective effects of inhibitors of hormone processing on insulin action in isolated hepatocytes. Endocrinology 114: 753-760

40. Roder ME, Knip M, Hartling SG, Karjalainen J, Akerblom HK, Binder C (1994) The Childhood Diabetes in Finland Study Group: Disproportionately elevated proinsulin levels precede the onset of insulin-dependent diabetes mellitus in siblings with low first phase insulin responses. $\mathbf{J}$ Clin Endocrinol Metab 79: 1570-1575 